Research Article

www.ijrap.net

\title{
IN VITRO ANTIOXIDATIVE PROFILING OF DIFFERENT EXTRACTS OF FAGONIA SCHWEINFURTHII (HADIDI) HADIDI
}

\author{
Anil Pareek*, Badri Prakash Nagori \\ Lachoo Memorial College of Science and Technology (Autonomous), Pharmacy wing, Jodhpur, Rajasthan, India
}

Received on: 04/06/13 Revised on: 20/07/13 Accepted on: 10/08/13

\author{
*Corresponding author \\ E-mail: pareekworld@gmail.com \\ DOI: $10.7897 / 2277-4343.04416$ \\ Published by Moksha Publishing House. Website www.mokshaph.com \\ All rights reserved.
}

\begin{abstract}
The present study was aimed to evaluate in vitro antioxidant activity of Fagonia schweinfurthii (Hadidi) Hadidi. F. schweinfurthii was successively extracted with different solvents such as petroleum ether, chloroform, ethyl acetate and methanol. The antioxidant activity of $F$. schweinfurthii extracts was investigated using different assays like 2,2-diphenyl-1-picryl hydrazyl (DPPH) radical scavenging activity, 2,2'-azino-bis(3ethylbenzthiazoline-6-sulfonic acid) (ABTS) diammonium salt radical scavenging activity, hydrogen peroxide $\left(\mathrm{H}_{2} \mathrm{O}_{2}\right)$ scavenging activity, nitric oxide (NO) scavenging activity, ferric reducing power and $\beta$-carotene bleaching assay. Total phenolic and flavonoid contents of the extracts were determined by using Folin-Ciocalteu method and aluminium chloride method, respectively in order to evaluate a relationship between the antioxidant activity and the phytochemical constituents. The F. schweinfurthii methanolic extract (FSME) exhibited significantly (p < 0.05) higher ABTS radical, $\mathrm{NO}$ radical and $\mathrm{H}_{2} \mathrm{O}_{2}$ scavenging activity, reducing power ability and inhibition of $\beta$-carotene bleaching. Total phenol and flavonoid contents were highest in the FSME $(94.61 \pm 1.51 \mathrm{mg} \mathrm{GAE} / \mathrm{g}$ and $21.52 \pm 0.17 \mathrm{mg} \mathrm{QE} / \mathrm{g})$ respectively. The present study showed that FSME had more antioxidant power than other extracts. Further studies are necessary to isolate active principles responsible for the overall antioxidant activity of the extracts. Keywords: Fagonia schweinfurthii, antioxidant, free radical scavenging activity, reducing power, phenols, flavonoid
\end{abstract}

\section{INTRODUCTION}

Living cells may generate free radicals and other reactive oxygen species (ROS) by products as a results of physiological and biochemical processes. The importance of free radicals and ROS has attracted increasing attention over the past decade. ROS, which include free radicals such as superoxide anion radicals $\left(\mathrm{O}_{2}{ }^{-}\right)$, hydroxyl radicals $\left(\mathrm{HO}^{-}\right)$and non-free-radical species, such as $\mathrm{H}_{2} \mathrm{O}_{2}$ and singled oxygen $\left(-\mathrm{O}_{2}\right)$, are various forms of activated oxygen. ROS are continuously produced during normal physiologic events and are removed by antioxidant defence mechanisms ${ }^{1}$. There is a balance between the generation of ROS and inactivation of ROS by the antioxidant system in organisms. Under pathological conditions, overproduction of ROS and other free radicals then can damage cellular proteins, carbohydrates, lipids and DNA and may thus lead to oxidative stress which in turn results in a variety of diseases, such as liver cirrhosis, inflammation, atherosclerosis, diabetes, cancer, neurodegenerative disease, nephrotoxicity and also the aging process ${ }^{2}$. Antioxidants can protect the human body from free radicals and ROS effects and retard the progress of many chronic diseases as well as lipid oxidative rancidity in foods ${ }^{3}$. The most commonly used antioxidants at the present time are butylated hydroxyanisole (BHA), butylated hydroxytoluene (BHT), propyl gallate and tertbutylhydroquinone. However, BHA and BHT have suspected of being responsible for liver damage and carcinogenesis ${ }^{4}$. Potential sources of antioxidant compounds have been searched in many types of plant materials such as fruits, leaves, seeds etc. As plants produce a lot of antioxidants to control the oxidative stress caused by sunbeams and oxygen, they can represent a source of new compounds with antioxidant activity. It has been observed that phytochemicals like tannic acid, flavonoids, tocopherol, curcumin, ascorbate, carotenoids, polyphenols, etc. were reported to have potent antioxidant properties ${ }^{5}$. Therefore, the importance of search for natural antioxidants has greatly increased in the recent years. So, many researchers have focused on natural antioxidants and in the plant kingdom numerous crude extracts and pure natural compounds were previously reported to have antioxidant properties. The genus Fagonia (Family: Zygophyllaceae) includes about 35 species that are distributed in the deserts and dry areas in India, tropical Africa, Chile and South West USA. The entire plants of various Fagonia species were investigated mainly for the presence of two major types of phytochemical compounds, i.e. flavonol glycosides and terpenoid glycosides ${ }^{6}$. Fagonia schweinfurthii (Hadidi) Hadidi and its closely related species (Fagonia indica) are widely distributed in desert region of India ${ }^{7}$. This plant is commonly known as 'Dhamasha' and is small spiny under-shrub. They are traditionally well known for the treatment of number of ailments such as jaundice, diabetes, joint pain, dropsy, cough, asthma, small-pox and against poisoning ${ }^{8,9}$ and skin eruptions ${ }^{10}$. An aqueous decoction of the whole plant is used to cure bile by local communities in Tapkeshwari hill of Bhuj Taluka, Kachchh, India ${ }^{11}$. Literature review reveals that $F$. schweinfurthii is unexplored with respect to its medicinal value. Earlier, this plant was identified as Fagonia indica Burn. var. schweinfurthii but later in 1973, it was named as Fagonia schweinfurthii (Hadidi) Hadidi ${ }^{7}$. After critical herbarium studies, the two species can be distinguished on these character i.e. leaves unifoliolate/ trifoliolate nature and capsule pedicel length. $F$. indica has unifoliolate leaves and pedicel equal to or shortens than capsule. El Hadidi recognized that $F$. schweinfurthii has trifoliolate and unifoliolate leaves with pedicel twice as 
long as capsule ${ }^{12}$. Lower leaves of $F$. schweinfurthii are three-foliolate and upper leaves are one-foliolate ${ }^{7}$. The anti-inflammatory and wound healing activities of $F$. schweinfurthii have been investigated ${ }^{13,14}$. The phytochemical analysis of the ethanol extract from $F$. schweinfurthii revealed the presence of flavonoids and phenolic compounds ${ }^{14}$. The flavonoids in many medicinal plants possess a wide range of bioactive capacities, especially their antioxidant activity. They can scavenge free radicals, increase the levels of antioxidant enzymes and thus protect body systems against damage from free oxygen species ${ }^{15-17}$. Hence, we hypothesized that $F$. schweinfurthii may be used as a natural antioxidants to control oxidative stress. The present study focused on evaluating the in vitro antioxidant activity of different extracts from $F$. schweinfurthii.

\section{MATERIALS AND METHODS Plant Material}

F. schweinfurthii was collected from Jodhpur district of Rajasthan, India and identified from Botanical Survey of India, Arid Zone Regional Centre, Jodhpur, India and a voucher specimen no. LMC/AP/002 was deposited in the college for future reference.

\section{Preparation of extract}

F. schweinfurthii (whole plant) was dried under shade at room temperature. After drying, plant was subjected to size reduction to a coarse powder by using dry grinder. The dried material was then successively extracted using non-polar (Petroleum ether), followed by less polar (chloroform), polar (ethyl acetate) and most polar (methanol) solvents in a soxhlet apparatus. The extracts were filtered and concentrated using a rotary evaporator and then evaporated to dryness. The extracts are named as $F$. schweinfurthii petroleum ether extract (FSPEE), $F$. schweinfurthii chloroform extract (FSCE), $F$. schweinfurthii ethyl acetate extract (FSEAE) and $F$. schweinfurthii methanol extract (FSME).

\section{Determination of total phenol content}

Total phenol content in extract was determined by the Folin-Ciocalteu assay with some modifications ${ }^{18}$. Briefly, $0.4 \mathrm{ml}$ of plant extract $(1 \mathrm{mg} / \mathrm{ml})$ was mixed with $2.0 \mathrm{ml}$ of Folin-Ciocalteu reagent (diluted 1:10 with distilled water) and allowed to stand for 5 minutes at room temperature. Then, $1.6 \mathrm{ml}$ of $1 \mathrm{M} \mathrm{Na}_{2} \mathrm{CO}_{3}$ was added and the mixtures incubated at room temperature for $2 \mathrm{~h}$. The absorbance was measured at $750 \mathrm{~nm}$ (Shimadzu UV-160 A Spectrophotometer, Shimadzu Corporation, Japan). A standard curve was prepared using gallic acid (10-100 $\mu \mathrm{g} / \mathrm{ml}$ ). Using the standard curve the total phenol content of extract was calculated. The total phenol content was expressed as gallic acid equivalent in $\mathrm{mg} / \mathrm{g}$ of dry extract.

\section{Determination of total flavonoid content}

The total flavonoid content (TFC) of the extract was determined using the aluminium chloride colorimetric assay ${ }^{18} .0 .5 \mathrm{ml}$ of the extract was separately mixed with $1.5 \mathrm{ml}$ methanol, $0.1 \mathrm{ml}$ of $10 \%$ aluminum chloride, 0.1 $\mathrm{ml}$ of $1 \mathrm{M}$ potassium acetate and $2.8 \mathrm{ml}$ of distilled water. Following incubation for 30 minutes at room temperature, absorbance of the reaction mixture was measured at wavelength of $415 \mathrm{~nm}$ with a Shimadzu UV-160A Spectrophotometer (Shimadzu Corporation, Japan). A standard curve was prepared using quercetin and linearity was obtained in the range of $1-10 \mu \mathrm{g} / \mathrm{ml}$. The total flavonoid content was expressed as quercetin equivalent in $\mathrm{mg} / \mathrm{g}$ of extract.

\section{DPPH radical scavenging activity}

The antioxidant activity of the plant extract and the standard were assessed on the basis of the radical scavenging effect of the stable DPPH free radical ${ }^{19}$. About $2.8 \mathrm{ml}$ of DPPH in methanol solution $(0.1 \mathrm{mM})$ was added to $0.2 \mathrm{ml}$ of the extract solution at various concentrations in a test tube. After incubation at $37^{\circ} \mathrm{C}$ for 30 minutes, the absorbance of each solution was determined at $517 \mathrm{~nm}$ using spectrophotometer. All measurements were made in triplicate and averaged. The radical scavenging activity was calculated as follows: \% scavenging activity $=\left[\left(\mathrm{A}_{\mathrm{s}}-\mathrm{A}_{\mathrm{i}}\right) / \mathrm{A}_{\mathrm{s}}\right] \times 100$, where $\mathrm{A}_{\mathrm{s}}$ is the absorbance of pure DPPH and $A_{i}$ is the absorbance of $\mathrm{DPPH}$ in the presence of various extracts. $\mathrm{IC}_{50}$ value is the concentration of the sample required to scavenge 50 $\%$ DPPH free radical. The $\mathrm{IC}_{50}$ was determined by interpolation from linear regression analysis of $\%$ scavenging activity against sample concentration $(\mu \mathrm{g} / \mathrm{ml})$ and the $\mathrm{IC}_{50}$ value decreases as a function of increasing antioxidant activity of samples. Vitamin $\mathrm{C}$ was used as reference.

\section{ABTS radical scavenging activity}

The ability to scavenge the ABTS radical cation $\left(\mathrm{ABTS}^{+}\right)$ was determined according to Re et $a l^{20}$. The $\mathrm{ABTS}^{+}$ solution was prepared by the reaction of $7 \mathrm{mM}$ ABTS (5 $\mathrm{ml})$ and $2.45 \mathrm{mM}(88 \mu \mathrm{l})$ potassium persulphate after incubation at room temperature in the dark for $16 \mathrm{~h}$. It was then diluted with $80 \%$ ethanol to obtain an absorbance of $0.900 \pm 0.05$ at $734 \mathrm{~nm}$. The $\mathrm{ABTS}^{+}$ solution $(3.6 \mathrm{ml})$ was thoroughly mixed with $0.4 \mathrm{ml}$ of the test sample. The reaction mixture was allowed to stand at $30^{\circ} \mathrm{C}$ for 30 minutes and the absorbance at $734 \mathrm{~nm}$ was immediately recorded. Vitamin $\mathrm{C}$ was used as reference. All assays were carried out in triplicate. The level of ABTS radical scavenging was calculated using the aforementioned equation for DPPH.

\section{Hydrogen peroxide scavenging activity}

The ability of extracts to scavenge hydrogen peroxide was determined according to the method of Ruch et $a l^{21}$ with slight modifications ${ }^{22}$. A solution of hydrogen peroxide (20 mM) was prepared in phosphate buffer ( $\mathrm{pH} 7.4) .1 .5$ $\mathrm{ml}$ of extract solution of various concentration were added to hydrogen peroxide solution $(3.5 \mathrm{ml})$. Absorbance of hydrogen peroxide at $230 \mathrm{~nm}$ was determined after 10 minutes against a blank solution containing phosphate buffer without hydrogen peroxide. For each concentration, a separate blank sample was used for background subtraction. The level of hydrogen peroxide scavenging was calculated using the aforementioned equation for DPPH. 


\section{Nitric oxide scavenging activity}

Sodium nitroprusside in aqueous solution at physiological $\mathrm{pH}$, spontaneously generates nitric oxide, which interacts with oxygen to produce nitrite ions, which can be estimated by the use of Griess Illosvoy reaction ${ }^{21}$. In the present investigation, Griess Illosvoy reagent is modified by using naphthylethylenediamine dihydrochloride $(0.1 \%$ $\mathrm{w} / \mathrm{v})$ instead of 1 naphthylamine $(5 \%)$. Scavengers of nitric oxide compete with oxygen leading to reduced production of nitric oxide. The reaction mixture $(6 \mathrm{ml})$ containing sodium nitroprussude $(10 \mathrm{mM}, 4 \mathrm{ml})$, phosphate buffer saline $(1 \mathrm{ml})$ and extract or standard solution $(1 \mathrm{ml})$ was incubated at $25^{\circ} \mathrm{C}$ for 150 minutes. After incubation, $1 \mathrm{ml}$ of the reaction mixture containing nitrite was pipetted and mixed with $2 \mathrm{ml}$ of sulphanilic acid reagent $(0.33 \%$ in $20 \%$ glacial acetic acid) and allowed to stand for 5 minutes for completing diazotization. Then, $2 \mathrm{ml}$ of naphthylethylenediamine dihydrochloride (1\%) was added, mixed and allowed standing for 30 minutes. A pink coloured chromophore was formed in diffused light. The absorbance of these solutions was measured at $540 \mathrm{~nm}$ using spectrophotometer against the corresponding blank solutions. The level of nitric oxide scavenging was calculated using the aforementioned equation for DPPH.

\section{Ferric reducing antioxidant power (FRAP) assay}

FRAP assay was done according to the protocol of Benzie and Strain $^{23}$ with some modifications ${ }^{18}$. The stock solutions were $300 \mathrm{mM}$ acetate buffer (3.1 g of Sodium acetate trihydrate and $16 \mathrm{ml}$ Glacial acetate buffer; $\mathrm{pH}$ 3.6), TPTZ solution (10 mM TPTZ in $40 \mathrm{mM} \mathrm{HCl})$ and $20 \mathrm{mM} \mathrm{FeCl} 3 \cdot 6 \mathrm{H}_{2} \mathrm{O}$ solution. Working FRAP solution was prepared freshly by mixing $25 \mathrm{ml}$ of acetate buffer, $2.5 \mathrm{ml} \mathrm{TPTZ}$ solution and $2.5 \mathrm{ml}$ of $\mathrm{FeCl}_{3} \cdot 6 \mathrm{H}_{2} \mathrm{O}$ solution and then warmed to $37^{\circ} \mathrm{C}$ before use. $0.15 \mathrm{ml}$ of extract solutions of various concentration was allowed to react with $2.85 \mathrm{ml}$ of FRAP solution for 30 minutes in dark. Absorbance of the colored product (ferrous tripyridyltriazine complex) was read at $593 \mathrm{~nm}$. FRAP values were calculated according to the calibration curve for $\mathrm{FeSO}_{4} \cdot 7 \mathrm{H}_{2} \mathrm{O}$ and FRAP values were expressed as mmol Fe (II)/100 g dry weight.

\section{$\beta$-Carotene bleaching assay}

Antioxidant activity was evaluated according to the $\beta$ carotene bleaching method with slight modifications ${ }^{24}$. A solution of $\beta$-carotene was prepared by dissolving $2 \mathrm{mg}$ of carotene in $10 \mathrm{ml}$ of chloroform. Two milliliters of this solution was pipette into a $500 \mathrm{ml}$ round bottom flask. After chloroform was removed under vacuum, $40 \mathrm{mg}$ of purified linoleic acid, $400 \mathrm{mg}$ of Tween 80 emulsifier, and $100 \mathrm{ml}$ of aerated distilled water were added to the flask with vigorous shaking. Aliquots $(4.8 \mathrm{ml})$ of this emulsion were transferred into different test tubes containing $0.2 \mathrm{ml}$ solution of sample. As soon as the emulsion was added to each tube, the zero time absorbance was measured at $470 \mathrm{~nm}$. The tubes were placed at $50^{\circ} \mathrm{C}$ in a water bath for 120 minutes to induce auto-oxidation and the absorbance was measured again. A negative control mixture was prepared similar to the sample mixture with the test solution/solvent instead of test sample. BHT was used as a reference standard. The capacity of the sample to protect against oxidation of $\beta$ carotene was determined as follows: $\% \quad \beta$-carotene bleaching inhibition $=\{$ (absorbance of negative control 0 $120 \mathrm{~min}$ ) - (absorbance of sample 0-120 $\mathrm{min})\}$ $\times 100 /$ (absorbance of negative control $0-120 \mathrm{~min}$ ). $\mathrm{IC}_{50}$ value that indicates the effective concentration that could inhibit $50 \% \quad \beta$-carotene bleaching activity, was detected from a nonlinear sigmoidal dose-response curve (GraphPadPrism, USA). All experiments were performed in triplicate.

Table 1: Total flavonoid and phenolic contents in different extracts of $F$. schweinfurthii

\begin{tabular}{|c|c|c|}
\hline & Total phenolic content (mg GAE/g extract) & Total flavonoid content (mg QE/g extract) \\
\hline FSPEE & $25.52 \pm 3.18^{\mathrm{d}}$ & $9.55 \pm 0.61^{\mathrm{c}}$ \\
\hline FSCE & $44.27 \pm 2.40^{\mathrm{c}}$ & $16.10 \pm 0.40^{\mathrm{b}}$ \\
\hline FSEAE & $59.89 \pm 1.80^{\mathrm{b}}$ & $17.33 \pm 0.65^{\mathrm{b}}$ \\
\hline FSME & $94.61 \pm 1.51^{\mathrm{a}}$ & $21.52 \pm 0.17^{\mathrm{a}}$ \\
\hline
\end{tabular}

Values are expressed as mean \pm SEM $(n=3)$; means in the same column followed by different letters are significantly different at $\mathrm{p}<0.05$ using Tukey's multiple range tests. Abbreviation: FSPEE, F. schweinfurthii petroleum ether extract; FSCE, F. schweinfurthii chloroform extract; FSEAE, F. schweinfurthii ethyl acetate extract; FSME, F. schweinfurthii methanol extract; QE, quercetin equivalents; GAE, gallic acid equivalents.

Table 2: Determination of DPPH, ABTS, $\mathrm{H}_{2} \mathrm{O}_{2}$, NO, $\beta$-Carotene-linoleic and FRAP scavenging activity using of $\boldsymbol{F}$. schweinfurthii in different extracts

\begin{tabular}{|c|c|c|c|c|c|c|}
\hline \multicolumn{7}{|c|}{$\mathrm{IC}_{50}(\mu \mathrm{g} / \mathrm{ml})$} \\
\hline & DPPH & ABTS & $\mathrm{H}_{2} \mathrm{O}_{2}$ & NO & $\beta$-Carotene & FRAP* \\
\hline FSPEE & $511.09 \pm 25.06^{\mathrm{d}}$ & $62.49 \pm 2.08^{\mathrm{d}}$ & $403.31 \pm 3.92^{\mathrm{e}}$ & $435.92 \pm 19.84^{\mathrm{d}}$ & $542.39 \pm 18.26^{\mathrm{e}}$ & $20.16 \pm 1.23^{\mathrm{d}}$ \\
\hline FSCE & $229.43 \pm 12.19^{c}$ & $28.03 \pm 0.36^{\mathrm{c}}$ & $378.13 \pm 6.31^{\mathrm{d}}$ & $263.57 \pm 7.74^{\mathrm{c}}$ & $450.70 \pm 8.09^{d}$ & $30.85 \pm 1.26^{\mathrm{c}}$ \\
\hline FSEAE & $139.65 \pm 7.82^{b}$ & $23.67 \pm 1.61^{\mathrm{c}}$ & $260.05 \pm 6.06^{\mathrm{c}}$ & $218.05 \pm 6.59^{\mathrm{b}, \mathrm{c}}$ & $370.76 \pm 4.10^{c}$ & $34.83 \pm 0.21^{\mathrm{b}}$ \\
\hline FSME & $90.85 \pm 4.87^{b}$ & $17.42 \pm 0.68^{b}$ & $232.42 \pm 4.36^{\mathrm{b}}$ & $176.71 \pm 3.59^{b}$ & $303.42 \pm 8.57^{b}$ & $49.52 \pm 1.13^{\mathrm{a}}$ \\
\hline Standard & $\begin{array}{c}7.3 \pm 0.46^{\mathrm{a}} \\
(\text { Vitamin } C)\end{array}$ & $\begin{array}{l}4.81 \pm 0.37^{\mathrm{a}} \\
(\text { Vitamin } C)\end{array}$ & $\begin{array}{c}20.11 \pm 1.98^{\mathrm{a}} \\
(\mathrm{BHA})\end{array}$ & $\begin{array}{l}52.73 \pm 3.43^{\mathrm{a}} \\
\text { (Rutin) }\end{array}$ & $\begin{array}{c}40.45 \pm 1.88^{\mathrm{a}} \\
(\mathrm{BHT})\end{array}$ & \\
\hline
\end{tabular}

Values are expressed as mean \pm SEM $(n=3)$; means in the same column followed by different letters are significantly different at $\mathrm{p}<0.05$ using Tukey's multiple range tests. *mmol Fe (II)/100 g dry extract

Abbreviation: FSPEE, F. schweinfurthii petroleum ether extract; FSCE, F. schweinfurthii chloroform extract; FSEAE, F. schweinfurthii ethyl acetate extract; FSME, F. schweinfurthii methanol extract; BHA, Butulated hydroxyanisole; BHT, Butylated hydroxytoluene. 
Anil Pareek et al / Int. J. Res. Ayurveda Pharm. 4(4), Jul-Aug 2013

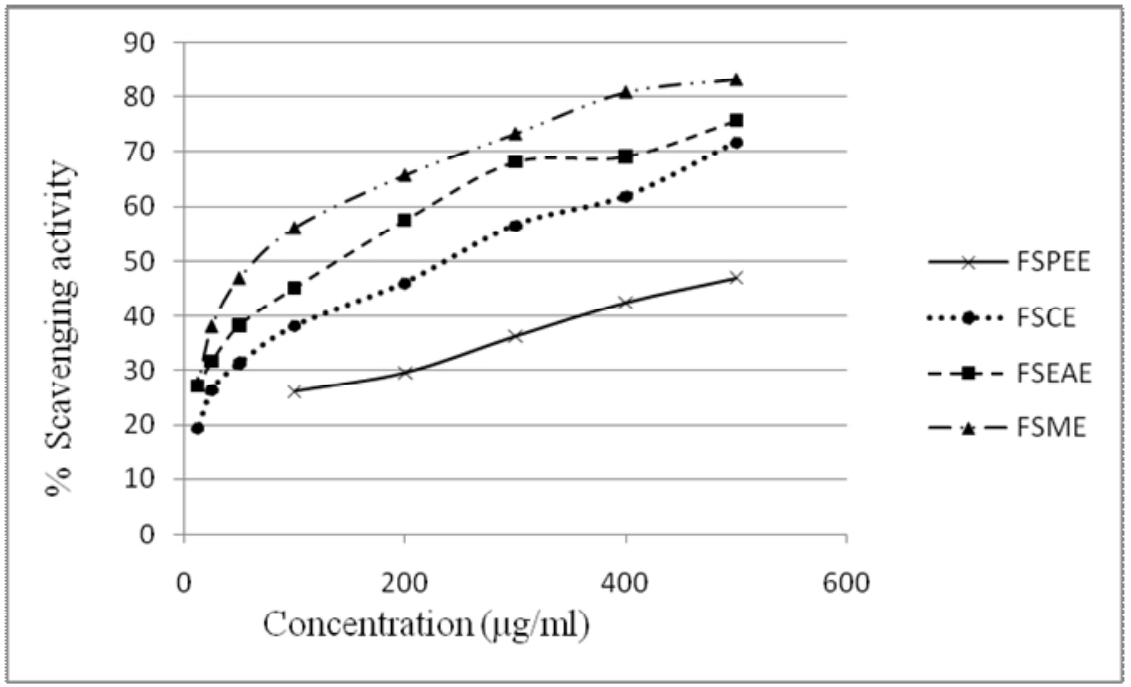

Figure (1 A): DPPH radical scavenging activity

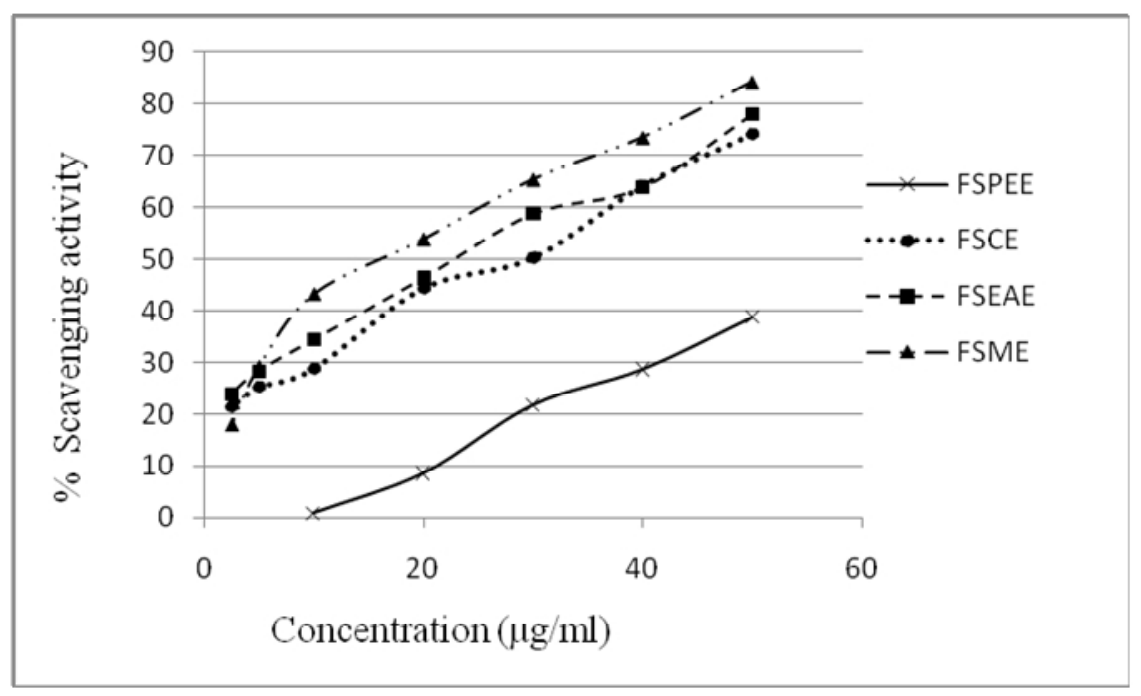

Figure (1B): ABTS radical scavenging activity

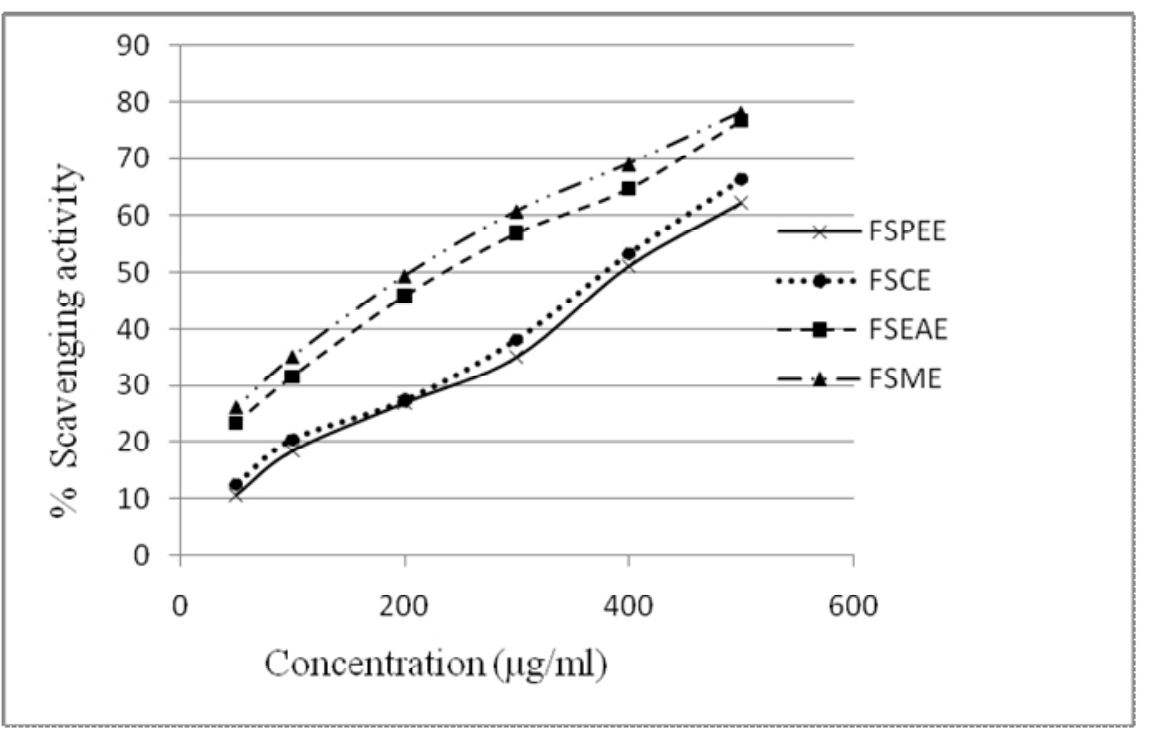

Figure (1C): Hydrogen peroxide $\left(\mathrm{H}_{2} \mathrm{O}_{2}\right)$ scavenging activity 


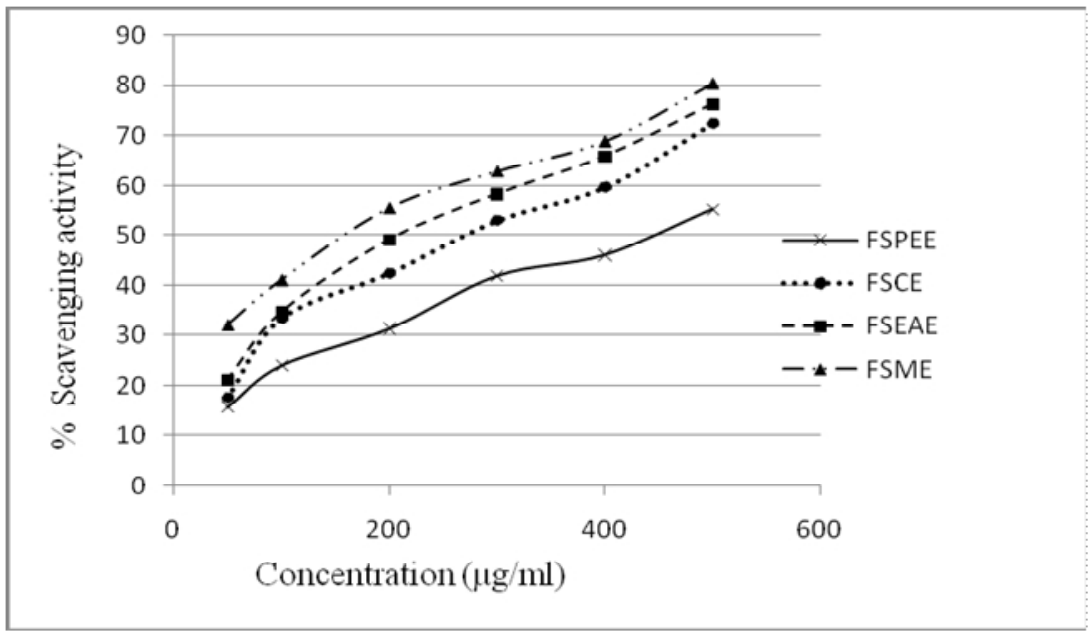

Figure (1D): Nitric oxide (NO) scavenging activity

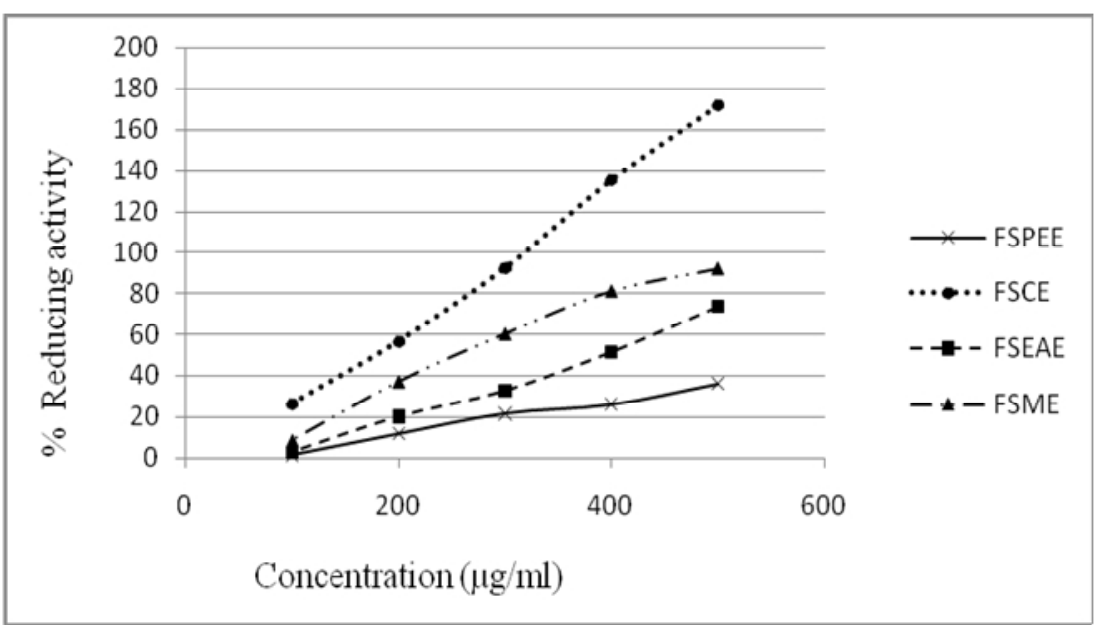

Figure (1E): Ferric reducing antioxidant power (FRAP) assay

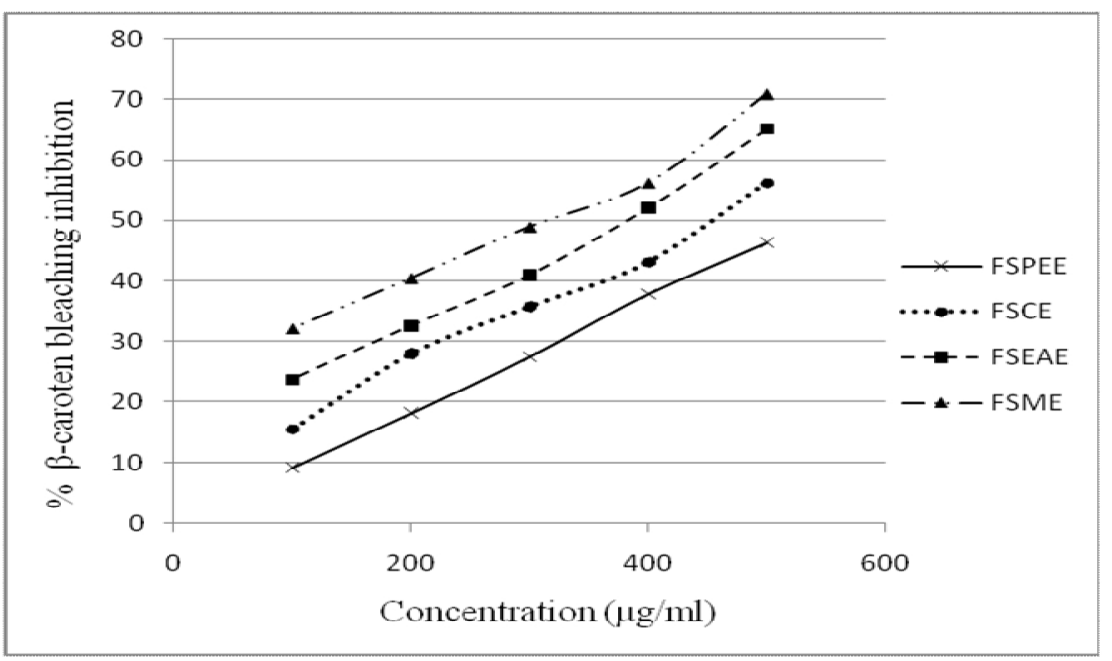

Figure (1F): $\beta$-Carotene bleaching assay

Figure 1: Antioxidant activity of different extracts from $F$. schweinfurthii FSPE, $F$. schweinfurthii petroleum ether extract; FSCE, $F$. schweinfurthii chloroform extract; FSEAE, F. schweinfurthii ethyl acetate extract; FSME, F. schweinfurthii methanol extract 


\section{Statistical analysis}

All the in vitro experimental results were expressed as mean \pm S.E.M. of three parallel measurements. The $\mathrm{IC}_{50}$ values were calculated by regression analysis. The data were subjected to one-way analysis of variance (ANOVA) followed by Tukey's multiple range tests using GraphPad Prism 4.0 Software, San Diego, CA, USA to establish the statistical significance. Values of $\mathrm{P}<0.05$ were considered significant in all cases.

\section{RESULTS AND DISCUSSION}

The differences in each antioxidant activity detection system depend on the unique characteristic of each test. Previous study shows that no single testing method is sufficient to estimate the antioxidant activity of a studied sample $^{25}$. Thus, the combination of various methods (i.e. scavenging activity on DPPH radicals, ABTS, NO, and $\mathrm{H}_{2} \mathrm{O}_{2}$, reducing power assay and $\beta$-carotene method) were used in this study to evaluate the antioxidant activity of $F$. schweinfurthii. In this study, $F$. schweinfurthii was successively extracted using non-polar (petroleum ether), followed by less polar (chloroform), polar (ethyl acetate) and most polar (methanol) solvents. A single solvent may not be enough to identify certain extracts responsible for the activity ${ }^{26}$.

\section{Total phenolic and flavonoid content}

The results of the total phenol and flavonoid content of $F$. schweinfurthii extracts are summarized in Table 1. In the present study, the total phenolic and flavonoid contents were found to be significantly $(\mathrm{p}<0.05)$ higher in FSME than other extracts of $F$. schweinfurthii. The total phenolic and flavonoid contents in the FSME were $59.89 \pm 1.8 \mathrm{mg}$ of GAEs/g of extract and $17.33 \pm 0.65 \mathrm{mg} \mathrm{QE} / \mathrm{g}$ of extract respectively. The high phenolic and flavonoid contents of the FSME may have contributed towards its antioxidant activity. Total phenolic and flavonoid compounds are largely responsible for the antioxidant activity of plant extract ${ }^{27}$. Total phenolic content was quantified using the Folin-Ciocalteau reagent, which is a widely used method for estimating total phenolic compounds. Phenols are one of the major groups of non-essential dietary components that have been associated with the inhibition of atherosclerosis and cancer, as well as for age-related degenerative brain disorders ${ }^{28}$. They can range from simple molecules, such as phenolic acids, to highly polymerized compounds, such as tannins. Flavonoids are water soluble polyphenolic compounds, which are extremely common and wide spread in the plant kingdom as their glycosides. Total flavonol is determined by colorimetric method using aluminium chloride. It is well documented that flavonoids and polyphenols are natural antioxidants. Flavonoids can directly react with superoxide anions and lipid peroxyl radical and consequently inhibit or break the chain of lipid peroxidation. This radical scavenging activity of extracts could be related to the antioxidant nature of polyphenols or flavonoids, thus contributing to their electron/hydrogen donating ability ${ }^{29,30}$. However, further studies are required to isolate the major phenolics and flavonoids present in $F$. schweinfurthii for its potent antioxidant properties.

\section{DPPH radical scavenging activity}

As depicted in Figure 1A, the DPPH radical scavenging activities of extracts increased with the concentrations. The percentage inhibition values of FSME, FSEAE, FSCE and FSPE were 46.99, 38.39, 31.37 and 22.59 respectively at the $50 \mu \mathrm{g} / \mathrm{ml}$ concentration. Results obtained in the study showed that the $\mathrm{IC}_{50}$ of $\mathrm{FSME}$ $(90.85 \pm 4.87 \mu \mathrm{g} / \mathrm{ml})$ was significantly $(\mathrm{p}<0.05)$ lower than that of other extracts; FSPEE $(511.09 \pm 25.06 \mu \mathrm{g} / \mathrm{ml})$ and FSCE (229.43 \pm 12.19) (Table 2). The FSME exhibited the greatest free radical scavenging activity, followed by the FSEAE, FSCE, and FSPE (Figure 1A). However, scavenging activity of Vitamin $\mathrm{C}\left(\mathrm{IC}_{50}: 7.3 \pm\right.$ 0.46), a known antioxidant used as a positive control was relatively more pronounced than that all extracts. DPPH radical scavenging assay is widely employed and preferred for the measurement of antioxidant activity, because of its imperviousness to the side and enzymatic reactions. DPPH in methanol occurs as free radical and showed pink colored solution which becomes faint after acquiring proton(s) from the antioxidant(s). Hence, measurement of reduction in the color intensity of methanolic DPPH solution may be used to evaluate the antioxidants' strength to donate proton.

\section{ABTS radical scavenging activity}

As shown in Figure 1B, the all F. schweinfurthii extracts exhibited ABTS radical scavenging effects in dose dependent manner and FSME showed more than $90 \%$ inhibition at the higher final concentrations (ranged between $2.5 \mu \mathrm{g} / \mathrm{ml}$ and $50 \mu \mathrm{g} / \mathrm{ml}$ ). The $\mathrm{IC}_{50}$ value of FSME $(17.42 \pm 0.68 \mu \mathrm{g} / \mathrm{ml})$ was significantly $(\mathrm{p}<0.05)$ lower than that of all other $F$. schweinfurthii extracts (Table 2, Figure 1B), which might be due to the fact that the FSME contains the highest levels of antioxidant compounds. The $\mathrm{ABTS}^{+}$scavenging assay, which employs a specific absorbance $(734 \mathrm{~nm})$ at a wavelength remote from the visible region and requires a short reaction time, can be used as an index that reflects the antioxidant activity of the test samples ${ }^{31}$.

\section{Hydrogen peroxide scavenging activity}

The hydrgen peroxide scavenging ability of different extracts from $F$. schweinfurthii on $\mathrm{H}_{2} \mathrm{O}_{2}$ is shown in Figure 1C. Result of the study showed that the antioxidant capacity of $F$. schweinfurthii extracts was significantly (p $<0.05$ ) lower than that of reference (Table 2). There was significant $(\mathrm{p}<0.05)$ difference on the scavenging capacity between FSME, FSCE, FSEAE and FSPEE. Hydrogen peroxide itself is not very reactive, but it may be toxic to cell since it may give rise to hydroxyl radicals in cells ${ }^{24}$. The $\mathrm{H}_{2} \mathrm{O}_{2}$ scavenging capacity of an extract may be attributed to the structural features of their active components, which determine their electron donating abilities $^{18}$.

\section{Nitric oxide scavenging activity}

Nitric oxide radicals generated from sodium nitroprusside was found to be inhibited by $F$. schweinfurthii extracts. The corresponding $\mathrm{IC}_{50}$ values for $\mathrm{NO}$ scavenging activity are presented in Table 2. All extracts exhibited NO scavenging activity but in different levels (Figure 1D). 
The FSME showed $32.08 \%$ inhibition at $50 \mu \mathrm{g} / \mathrm{ml}$, indicating good NO scavenging activity (Figure 1D). The NO scavenging activitiy of the extracts was lower than rutin $(48.43 \%$ inhibition at $50 \mu \mathrm{g} / \mathrm{ml})$. Probably the phenolic and flavonoid compounds present in $F$. schweinfurthii extracts contributed in scavenging of nitric oxide. Similarly, Srinivasa et al. also reported the high positive correlation of phenolic and flavonoid content with NO scavenging activity of extract obtained from Chromolaena odorata leaves ${ }^{32}$. NOs as free radicals involves in various types of inflammation in the body therefore, with regard to the NO scavenging activity of the extracts they could be applied as anti inflammatory agent.

Ferric reducing antioxidant power (FRAP) assay

The FRAP assay is based on the reduction of the ferric tripyridyl triazine $\left(\mathrm{Fe}^{3+}-\mathrm{TPTZ}\right)$ complex to its colored ferrous tripyridyl triazine $\left(\mathrm{Fe}^{2+}-\mathrm{TPTZ}\right)$ form and the assay directly measures the amount of antioxidants or reductants in the sample ${ }^{33}$. Results depict that the reducing power of $F$. schweinfurthii extracts increases with increasing concentration which implies that the extract is capable of donating $\mathrm{H}$ atoms in a dose dependent manner (Figure 1E). The reducing power of all tested extracts varied significantly $(\mathrm{p}<0.05$; Table 2$)$. The FSME showed significantly $(\mathrm{p}<0.05)$ the highest reducing activity among the extracts of $F$. schweinfurthii with $49.52 \pm 1.13 \mathrm{mmol}$ Fe (II)/100 g dry extract (Table 2). The results presented revealed that the FSME extract has the highest electron donating capacity possibly contained higher amounts of reductones. FRAP values of FSME correlates with the results obtained in phenolic content assays.

\section{$\beta$-Carotene bleaching assay}

The $\beta$-carotene bleaching assay was used for further comparative antioxidant assessment of $F$. schweinfurthii extracts. This assay is based on the capacity of antioxidant to retard $\beta$-carotene oxidation (discoloring) induced by the products from linoleic acid oxidative degradation. The dose dependent $\beta$-carotene bleaching effects of the $F$. schweinfurthii extracts are presented in Figure 1F. At concentrations $500 \mu \mathrm{g} / \mathrm{ml}$, FSME exhibited $70.79 \%$ of lipid peroxidation inhibition while BHT $(200 \mu \mathrm{g} / \mathrm{ml})$ displayed more than $85 \%$ of inhibition. Among the $F$. schweinfurthii extracts, the FSPEE showed significantly $(\mathrm{p}<0.05)$ the weakest antioxidant activity while the FSME presented significantly $(\mathrm{p}<0.05)$ the strongest activity. However, the $\beta$-carotene bleaching power of the positive reference standards (BHT) was significantly more pronounced than the tested extracts (Table 2). Bleaching of $\beta$-carotene is a free-radical-mediated phenomenon resulting from the hydroperoxides formed from linoleic acid by air oxidation. In the absence of antioxidants, the $\beta$-carotene molecules lose their double bonds by oxidation as well as the characteristic orange colour, which can be monitored spectrophotometrically. The presence of different antioxidants can hinder the extent of and other free radicals formed in the system ${ }^{34}$. Thus, this forms the basis by which $F$. schweinfurthii extracts could be screened for their antioxidant potential.
The antioxidant activity ability of the plant extracts basically depend on the composition of the extracts, hydrophobic or hydrophilic nature of the antioxidants, type of solvent used for extraction process, method of extraction, temperature and conditions of the test systems. Therefore, it is necessary to use more than one method for evaluation of antioxidant activity of plant extracts defining various mechanisms of antioxidant actions ${ }^{35}$.

\section{CONCLUSION}

On the basis of the results of this study, it is clearly indicated that $F$. schweinfurthii has a powerful antioxidant activity against various oxidative systems in vitro; moreover, $F$. schweinfurthii can be used as accessible source of natural antioxidants and as a possible food supplement or in pharmaceutical industry. The various antioxidant mechanisms of $F$. schweinfurthii may be attributed to strong hydrogen donating ability, reducing ability and their effectiveness as scavengers of hydrogen peroxide and free radicals. The Phenolic and favonoid compounds appear to be responsible for the antioxidant activity of $F$. schweinfurthii. Thus, this easily available plant can be used as potential antioxidant. However, further work is required to evaluate in vivo antioxidant activity and to isolate and identification of the antioxidant component present in it.

\section{REFERENCES}

1. Nagmoti DM, Khatri DK, Juvekar PR, Juvekar AR. Antioxidant activity and free radical-scavenging potential of Pithecellobium dulce Benth seed extracts. Free Rad Antiox 2012; 2: 37-43. http://dx.doi.org/10.5530/ax.2012.2.2.7

2. Halliwell B. Reactive oxygen species in living systems: source, biochemistry and role in human disease. American J Med 1991; 91: 14-22. http://dx.doi.org/10.1016/0002-9343(91)90279-7

3. Rathore GS, Suthar M, Pareek A, Gupta RN. Nutritional antioxidants: A battle for better health. J Nat Pharm 2011; 1: 2-14. http://dx.doi.org/10.4103/2229-5119.78490

4. Gulcin I, Kufrevioglu OI, Oktay M, Buyukokuroglu ME. Antioxidant, antimicrobial, antiulcer and analgesic activities of nettle (Urtica dioica L.). J. Ethnopharmacol 2004; 90: 205-215. http://dx.doi.org/10.1016/j.jep.2003.09.028 PMid:15013182

5. Jayaprakasha GK, Selvi T, Sakariah KK. Antibacterial and antioxidant activities of grape (Vitis vinifera) seed extract. Food Res Int2003;36:117-122.http://dx.doi.org/10.1016/S0963-9969(02)0 0116-3

6. Saeed MA, Sabir AW. Effects of Fagonia cretica L. constituents on various haematological parameters in rabbits. J Ethnopharmacol 2003;85: 195-200. http://dx.doi.org/10.1016/S0378-8741(02)003653

7. Bhandari MM. Flora of the Indian Desert, Scientific Publishers, Jodhpur, India; 1990.

8. Kirtikar KR, Basu BD. Indian Medicinal Plants, third ed. Indological and Orient Publishers, New Delhi; 2000.

9. Singh V, Pandey RP. Ethnobotany of Rajasthan, Scientific Publishers, Jodhpur, India; 1998.

10. Qureshi R, Bhatti GR. Ethnobotany of plants used by the Thari people of Nara Desert, Pakistan. Fitoterapia 2008; 79: 468-473. http://dx.doi.org/10.1016/j.fitote.2008.03.010 PMid:18538950

11. Patel YS, Joshi EP, Joshi PN. Ethnobotanical study of Tapkeshwari Hill, Bhuj, Kachchh, India. Life Sci Leaflets 2010; 2: 22-31.

12. El Hadidi MN. Revision of Fagonia species with tri- to unifoliolate and simple leaves. Oesterr Bot Z 1973; 121: 269-278. http://dx.doi .org/10.1007/BF01375746

13. Alqasoumi SI, Yusufoglu HS, Alam A1. Anti-inflammatory and wound healing activity of Fagonia schweinfurthii alcoholic extract herbal gel on albino rats. African J Pharm Pharmacol 2011; 17: 1996-2001.

14. Rathore AS, Lohar V, Kumar R, Choudhary V, Bhandari A. Chemical composition and anti-inflammatory activity of various 
extracts of Fagonia schweinfurthii Hadidi. Med Chem Drug Discovery 2012; 3: 30-36.

15. Pietta PG. Flavonoids as antioxidants. J Natl Prod 2000; 63: 1035 1042. http://dx.doi.org/10.1021/np9904509 PMid:10924197

16. Tachakittirungrod S, Okonogi S, Chowwanapoonpohn S. Study on antioxidant activity of certain plants in Thailand: mechanism of antioxidant action of guava leaf extract. Food Chem 2007; 103: 381-388. http://dx.doi.org/10.1016/j.foodchem.2006.07.034

17. Terao J. Dietary flavonoids as antioxidants. Forum Nutr 2009; 61: 87-94. http://dx.doi.org/10.1159/000212741 PMid:19367113

18. Sharma A, Bhardwaj S, Mann AS, Jain A, Kharya MD. Screening methods of antioxidant activity: An overview. Phcog Rev 2007; 2: 232-238.

19. Brand Williams W, Cuvelier ME, Berset C. Use of a free-radical method to evaluate antioxidant activity. Food Chem Toxicol 1995; 28: 25-30.

20. Re R, Pellegrini N, Proteggente A, Pannala A, Yang M, Rice Evans C. Antioxidant activity applying an improved ABTS radical cation decolorization assay. Free Radical Bio Med 1999; 26: 1231-1237. http://dx.doi.org/10.1016/S0891-5849(98)00315-3

21. Ruch RJ, Cheng SJ, Klaunig JE. Prevention of cytotoxicity and inhibition of intercellular communication by antioxidant catechins isolated from Chinese green tea. Carcinogen 1989; 10: 1003-1008. http://dx.doi.org/10.1093/carcin/10.6.1003

22. Pareek A, Suthar M, Rathore G, Bansal V. In vitro antioxidant studies of Lagerstroemia speciosa leaves. Phcog J 2010; 2: 357 360. http://dx.doi.org/10.1016/S0975-3575(10)80109-9

23. Benzie IFF, Strain JJ. The ferric reducing ability of plasma (FRAP) as a measure of antioxidant power: the FRAP assay. Anal. Biochem 1996;239:70-76.http://dx.doi.org/10.1006/abio.1996.0292 PMid:86 60627

24. Bo Huang, Xiaoquan Ban, Jingsheng He, Hong Zeng, Peng Zhang, Youwei Wang. Hepatoprotective and antioxidant effects of the methanolic extract from Halenia elliptica. J Ethnopharmacol 2010; 131:276-281.http://dx.doi.org/10.1016/j.jep.2010.06.029 PMid:20 600758

25. Erel O. A novel automated method to measure total antioxidant response against potent free radical reactions. Clin Biochem 2004; 37: 112-119. http://dx.doi.org/10.1016/j.clinbiochem.2003.10.014 PMid:14725941

26. Yan XJ, Fang GM, Lou QX. Studies on free radical scavenging activity in Chinese seaweeds. Part1. Screening results. Chin J
Oceanol Limnol 1999; 17: 240-246. http://dx.doi.org/10.1007/ BF02842601

27. Rao KS, Munjuluri PR, Kumar BVVR, Keshar NR. Evaluation of in vitro antioxidant activity and total phenolic content of methanol bark extract of Mimusops elengi. Free Rad Antiox 2011; 1: 62-71. http://dx.doi.org/10.5530/ax.2011.2.11

28. Cheung LM, Cheung PC, Ooi VEC. Antioxidant activity and total phenolics of edible mushroom extracts. Food Chem 2003; 81: 249 255. http://dx.doi.org/10.1016/S0308-8146(02)00419-3

29. Tachakittirungrod S, Okonogi S, Chowwanapoonpohn S. Study on antioxidant activity of certain plants in Thailand: mechanism of antioxidant action of guava leaf extract. Food Chem 2007; 103 : 381-388. http://dx.doi.org/10.1016/j.foodchem.2006.07.034

30. Terao J. Dietary flavonoids as antioxidants. Forum Nutr 2009; 61: 87-94. http://dx.doi.org/10.1159/000212741 PMid:19367113

31. Wu LC, Hsu HW, Chen YC, Chiu CC, Lin YI, Ho JA. Antioxidant and antiproliferative activities of red pitaya. Food Chem 2006; 95 : 319-327. http://dx.doi.org/10.1016/j.foodchem.2005.01.002

32. Srinivasa KR, Chaudhury PK, Pradhan A. Evaluation of antioxidant activities and total phenolic content of Chromolaena odorata. Food Chem Toxicol 2010; 48: 729-732. http://dx.doi.org/10.1016/ j.fct.2009.12.005 PMid:20026159

33. Annegowda HV, Anwar LN, Mordi MN, Ramanathan S, Mansor SM. Influence of sonication on the phenolic content and antioxidant activity of Terminalia catappa L. leaves. Phcog Res 2010; 2: 368373. http://dx.doi.org/10.4103/0974-8490.75457 PMid:21713141 PMCid:PMC3111697

34. Patel V, Shukla S, Patel S. Free Radical Scavenging Activity of Grangea maderaspatana Poir. Phcog Mag 2009; 5: 381-387. http://dx.doi.org/10.4103/0973-1296.58156

35. Wong C, Li H, Cheng K, Chen F. A systematic survey of antioxidant activity of 30 Chinese medicinal plants using the ferric reducing antioxidant power assay. Food Chem 2006; 97: 705-711. http://dx.doi.org/10.1016/j.foodchem.2005.05.049

\section{Cite this article as:}

Anil Pareek, Badri Prakash Nagori. In vitro antioxidative profiling of different extracts of Fagonia schweinfurthii (Hadidi) Hadidi. Int. J. Res. Ayurveda Pharm. 2013;4(4):533-540 http://dx.doi.org/10.7897/2277$\underline{4343.04416}$ 